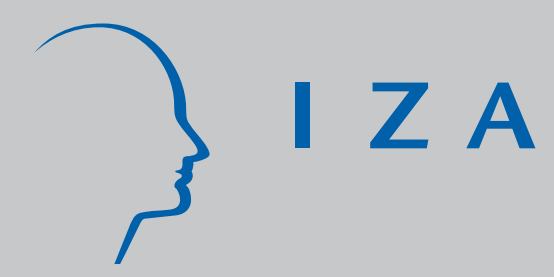

IZA DP No. 3903

Speed Discounting and Racial Disparities: Evidence from Speeding Tickets in Boston

Nejat Anbarci

J ungmin Lee

December 2008 


\title{
Speed Discounting and Racial Disparities: Evidence from Speeding Tickets in Boston
}

\author{
Nejat Anbarci \\ Deakin University \\ Jungmin Lee \\ Florida International University \\ and IZA
}

Discussion Paper No. 3903

December 2008

\author{
IZA \\ P.O. Box 7240 \\ 53072 Bonn \\ Germany \\ Phone: +49-228-3894-0 \\ Fax: +49-228-3894-180 \\ E-mail: iza@iza.org
}

\begin{abstract}
Any opinions expressed here are those of the author(s) and not those of IZA. Research published in this series may include views on policy, but the institute itself takes no institutional policy positions.

The Institute for the Study of Labor (IZA) in Bonn is a local and virtual international research center and a place of communication between science, politics and business. IZA is an independent nonprofit organization supported by Deutsche Post World Net. The center is associated with the University of Bonn and offers a stimulating research environment through its international network, workshops and conferences, data service, project support, research visits and doctoral program. IZA engages in (i) original and internationally competitive research in all fields of labor economics, (ii) development of policy concepts, and (iii) dissemination of research results and concepts to the interested public.
\end{abstract}

IZA Discussion Papers often represent preliminary work and are circulated to encourage discussion. Citation of such a paper should account for its provisional character. A revised version may be available directly from the author. 
IZA Discussion Paper No. 3903

December 2008

\title{
ABSTRACT
}

\section{Speed Discounting and Racial Disparities: Evidence from Speeding Tickets in Boston}

\begin{abstract}
Law enforcement officers are allowed to exercise a significant amount of street-level discretion in a variety of ways. In this paper, we focus on a particular prominent kind of discretionary behavior by traffic officers when issuing speeding tickets, speed discounting. Officers partially forgive motorists by writing a lower speed level than the speed that officers observe. Verifying the level of speed discounting by different groups of officers and motorists and ascertaining the presence of racial disparities in this lenient policing are the main objectives of this paper. We find that minority officers, particularly African-Americans, are harsher on all motorists but even harsher on minority motorists regarding speed discounting. The minority-on-minority disparity appears to be stronger in situations involving Hispanic officers, infrequently ticketing officers, male motorists, those driving old vehicles, and minority neighborhoods.
\end{abstract}

JEL Classification: J70, K42

Keywords: $\quad$ police discretion, disparate treatment, racial bias, speeding tickets

Corresponding author:

Jungmin Lee

Department of Economics

Florida International University

Miami, FL 33199

USA

E-mail: leej@fiu.edu

\footnotetext{
We are very grateful of Bill Dedman, Brian Knight, and Nicola Persico for providing the Massachusetts data and Carl Fever for providing the City of Bloomington data. We would like to thank Kate Antonovics, Mustafa Caglayan, Hyunbae Chun, Monica Escaleras, Hanming Fang, Daniel Hamermesh, Cem Karayalcin, Jinyoung Kim, Patrick Mason, Oscar Mitnik, Nicola Persico, Phil Robins, Richard Romano, Peter Thompson, Mehmet Ulubasoglu, and participants in seminars at several universities for helpful comments.
} 
Although [the officer] wrote the man a ticket for only 10 m.p.h. over the 35 m.p.h. limit, he made a note in the top right-hand corner of the ticket: "64." Through a Boston police spokeswoman, [he] said that notation meant the driver was actually going 64 m.p.h., a 29 m.p.h. over the limit. The spokeswoman said [the officer] would sometimes lower the speed on a ticket, to save a driver a high fine. But the notation was there in case the driver challenged the ticket in court. (Bill Dedman and Francie Latour, The Boston Globe, July 20, 2003)

\section{INTRODUCTION}

Police officers are allowed to exercise a significant deal of street-level discretion. A crucial issue is to ascertain whether they use their bestowed power appropriately for the sake of effective policing (e.g. overlooking mildly-speeding vehicles to facilitate the traffic flow) A strict officer is one who does not use any discretion. Observing a speeding vehicle, a strict officer will stop it, give a ticket to the motorist, and impose a fine according to the statutory formula. In reality, however, an officer using discretion could 1) not even stop the vehicle, 2) stop it but just let it go with an oral warning, 3) stop and give a written warning, or 4) issue a ticket but discount the speed and/or the fine. ${ }^{1}$ Vario us factors such as the driver's attitude, age, gender, race, and financial situation - as much as the latter can be judged by officers apparently play significant roles in officers' discretion. ${ }^{2}$

In this paper, we focus on a particular prominent type of discretionary behavior - speed discounting; officers give a "break' to motorists by reporting a lower speed level than the ir

\footnotetext{
${ }^{1}$ There are also subtle things that officers can control, such as length of stopping time, language, and friendliness, which can affect the disutility of the motorist.

2 "There are always mitigating circumstances in a stop," an officer said in an interview with the Boston Globe. "Anything could be said or could happen. Attitudes, people talking back to you. The circumstances change with each individual driver." The same officer also admitted that he rarely gave fines to elderly drivers, "presuming they were on a fixed income" (Dedman and Latour, 2003).
} 
actual speed (as shown in the above quote). A crucial question here is whether there exist racial disparities in speed discounting benefits that motorists receive, that is, whether, say, minority motorists are more harshly treated by white officers, whether minority officers are less lenient to minority motorists, and so on

\section{Figure 1. Histogram of Speed on Tickets}

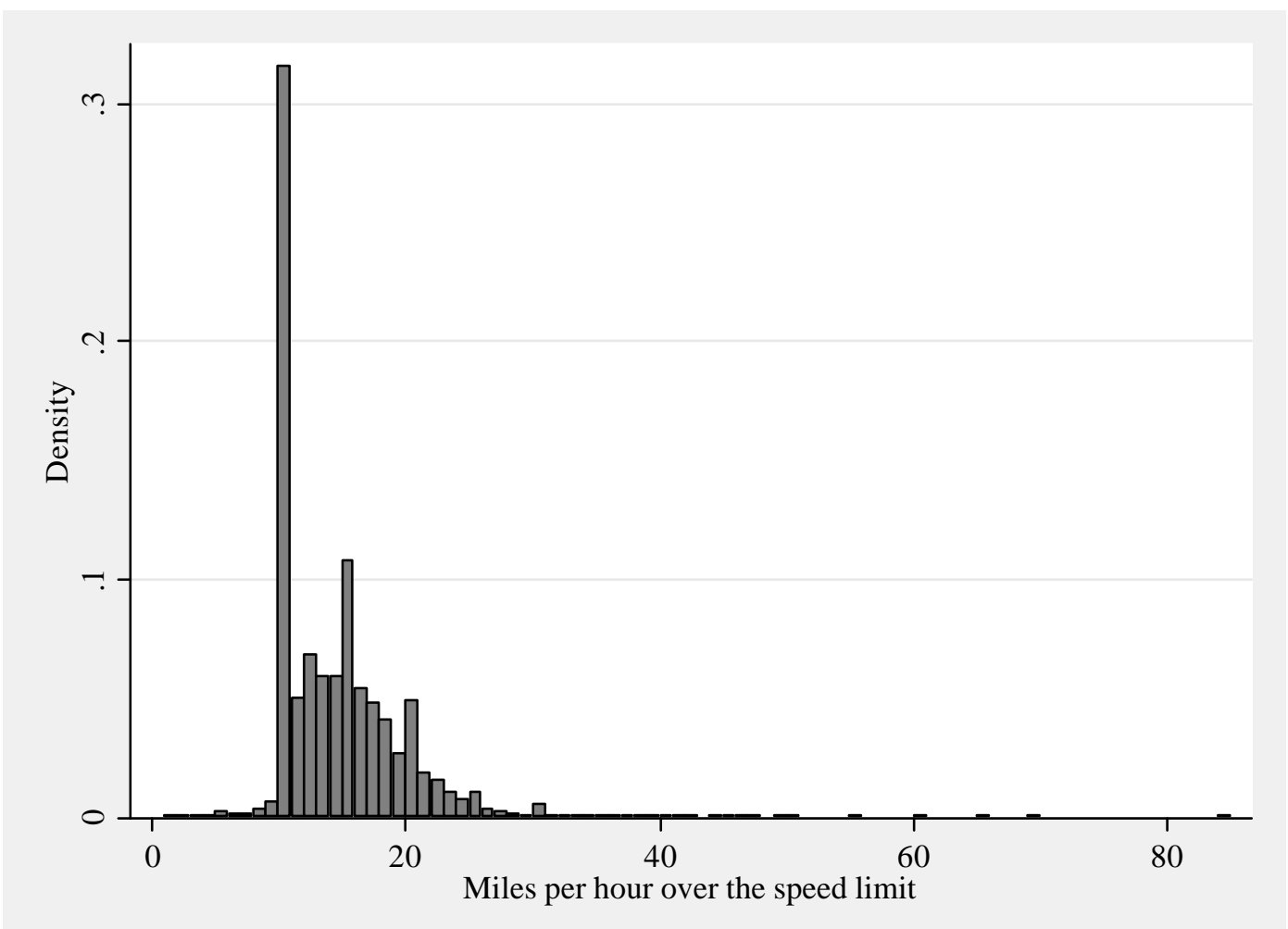

Figure 1 can serve as an important starting point to illustrate that speed discounting is very prevalent indeed. The graph is the histogram of reported speed on 25,738 speeding tickets issued by Boston police officers from April 2002 to November 2003. Observe that more than $30 \%$ of tickets are cited for driving exactly at 10 m.p.h. over the limit (hereafter, unless otherwise noted, the speed is always denoted as the miles per hour above the limit). There exist other less outstanding spikes at some specific speed levels, such as 15 and 20. The above graph shows, first of all, that the speed reported on tickets - especially at the spikes - 
should not be the actual speed. ${ }^{3}$ Rather, the histogram shows that officers' discretionary speed reporting distorts the distribution especially in the range 10-14. As we will elaborate later, conditional on getting ticketed at speed levels such as 10 or slightly higher, the fact that a motorist gets cited for driving at 10 will most likely indicate that the officer gives a break to the motorist. If this empirical strategy of exploiting the spike at 10 to elicit officers' discretionary behavior is valid, we can test for racial disparities in speed discounting by comparing the probability of getting cited exactly at 10 across different pairs of officers' and motorists' races.

Using the data on the 20-month record of speeding tickets (and the two-month record of warnings) issued by Boston traffic officers, we find that with respect to speed discounting, minority officers are harsher on all motorists, but they are even harsher on minority motorists. The finding is robust when controlling for motorists' zip code as well as neighborhoods where citations were issued and when correcting for the potential selection bias associated with officers' strategic ticketing behavior. Our main finding appears to be stronger among Hispanic officers, infrequently ticketing officers, male motorists, those driving old vehicles, and those driving in minority residential neighborhoods.

Although minority officers too give speed discounting, those who give speed discounting are predominantly white officers. We also find that male officers and inexperienced young officers are more likely to exhibit discretionary behavior. We find no gender disparity and little evidence on disparate treatment by motorists' age.

It is clear that our findings reflect something much more complicated than officers' pure preference-based racial bias. In order to account for our findings comprehensively, it is important to know the status of minority officers within the police force and perceptions regarding them in the communities they serve, while knowing interactions between officers

\footnotetext{
${ }^{3}$ Clarke (1996), using about 16.5 million observations in Illinois, found that the speed distribution - recorded mechanically, not by officers - is normally distributed and centered at the speed limit under free flow conditions.
} 
and motorists during stops as well as motorists' driving records (which are not currently being collected in any racial profiling data) in more detail would of course be invaluable. We will later elaborate on the former aspect more.

The paper is organized as follows. Section II discusses the related literature. Section III introduces the data and explains the empirical identification strategy of exploiting the clustering of tickets at the speed of 10. Section IV presents regression results and robustness checks. In Section V we ask a question of social significance, that is, why minority officers are harsher on minority motorists. Section VI concludes.

\section{RELATED LITERATURE}

It is worth pointing out, at the outset, how the present paper and research topic are related to the recently growing literature on racial profiling in vehicle searches. ${ }^{4}$ The main point here is that ticketing and vehicle searching behavior are two very different animals in nature. First, in the case of speeding violation, officers can - albeit with some error - first directly observe the degree of the offense, i.e. the speed over the limit (the researcher observes only the speed reported by the officer). Thus, the remaining decision is as to how strictly they would handle the case. Consequently, eliciting officers' discretionary behavior is possible in this case. On the other hand, in the case of vehicle searching, an officer is supposed to conduct a search

\footnotetext{
${ }^{4}$ The identification approaches are various, and the results are mixed. Knowles, Persico and Todd (2001) show that racially biased monitoring implies that the equilibrium rate at which contraband is seized (the "hit rate") is lower for the groups subject to bias. In some data sets, the race of officers is also observable, which makes different approaches feasible. Antonovics and Knight (2004) use the same Boston datathat we use in this paper and test whether officers are more likely to conduct a search if the race of the officer differs from that of the driver. Anwar and Fang (2006) propose a new test (the rank-order test) for relative racial prejudice based on a behavioral model. Using the Florida highway data, they cannotreject the null hypothesis of no racial bias, which does not mean, as they emphasize in the paper, that racial bias does not exist. Close and Mason (2007) develop a pairwise-comparison outcome test and, using the same Florida data, reject the null hypothesis of no discrimination.
} 
without first observing the presence of any illegal behavior. Thus, such an officer will necessarily try to infer a probability of an offense by processing all information available to him/her - including the race of the motorist. This mind process is unobservable even to the motorist, so it is difficult for any third party (including the econometrician) to figure out whether the officer used the driver's race as a productive resource (Persico, forthcoming).

It is generally true that officers would treat certain motorists more strictly if the se motorists seem likely to break the law in the future when treated leniently. In the case of speeding tickets, however, it seems unlikely that race is informative of such recidivism particularly for moderate speeders like those we focus on in this paper. Furthermore, it is hard to believe that the degree of strictness when issuing speeding tickets will alter motorists' speeding behavior since driving style is found to be habitual to an exte nt (Lawpoolsri et al., 2007).

Second, in the case of vehicle searching, officers deal with those who are potentially major offenders and felons. Thus, it may make sense that officers target a particular segment of population (e.g. a particular race) given the "hit rate" criterion. On the other hand, speeding motorists are likely to be "non-criminal" people (in fact, a strong case could be made that criminals would not speed rationally). Similarly, while most officers might consider vehicle searching a high-risk task, issuing speeding tickets is likely to be considered "mundane" or "routine." Lastly, officers who are lenient in vehicle searches could easily be accused of violating laws, while leniency in issuing speeding tickets would even be considered "humane." In sum, it would not be surprising to find that officers behave differently in these two cases.

While to date there is no work on speed discounting in particular - or officer leniency in general - and racial disparities in that context, a related strand of research too concerns officers' decision-making regarding whether they issue tickets (or warnings) to a driver with certain characteristics. Most papers in this strand attempt to elicit racial preferences of officers from their ticketing behavior, that is, whether to issue a ticket or a warning to a 
particular driver. The state-sponsored Northeastern Study (Farrell et al., 2004) uses the same data that we use in this paper. Their general results reveal that there are major disparities in ticketing behavior of officers of different races and genders to motorists of different races and genders. ${ }^{5}$ The study has been criticized in that it employs the standard benchmark test, which basically compares the shares of racial minorities in the population to their shares in the sample of drivers ticketed. It is, however, found that the racial composition of Census-based residential population poorly represents the racial composition of drivers on the road. ${ }^{6}$ Also there is no mention of the speed-discounting phenomenon in this extensive study - nor in any other study on officers' ticketing behavior that will be summarized below.

There have been attempts to overcome the so-called "denominator problem" in the benchmark approach. McConnell and Scheidegger (2001) compared tickets issued by airpatrol officers and by ground-patrol officers. The assumption is that the race of the driver cannot be determined by the air-patrol officer. They matched ground-patrol and air-patrol speeding tickets across day of week and time of day in Charleston, South Carolina. They found that a smaller proportion of African-Americans received ground-patrol citations than air-patrol citations. Grogger and Ridgeway (2006) compared the race distribution of drivers stopped during daylight with the counterpart distribution at night. Using the data from Oakland, California, they find no strong evidence on racial profiling. Ridgeway (2006) used the propensity score matching method to construct comparable groups and studied the same Oakland data. It turned out that "black drivers are significantly less likely to be cited than non-black drivers, black drivers are slightly less likely to be cited than white drivers, and white and non-white drivers are not cited at significantly different rates" (p. 19).

\footnotetext{
${ }^{5}$ This naturally raises a red flag regarding the officers' intentions given that a study by Lamberth (1996), which examined driving habits of African-American and white motorists on Maryland highways, found no difference in the rate at which thes e two segments of motorists engaged in speeding.

${ }^{6}$ For criticism about the residential population benchmark approach, refer to Riley and Ridgeway (2004) and, more generally, Engel and Calnon (2004).
} 
Some papers looked at issues other than racial disparities in officers' behavior. B lalock, DeVaro, Leventhal, and Simon (2007) examined traffic ticketing data from Bloomington and Highland Park in Illinois, Wichita, Boston, and the entire state of Tennessee and found out that women are more likely to receive citations in three of the five locations and men are more likely to receive citations in the other two locations. Makowsky and Stratmann (forthcoming), using the Massachusetts traffic data that Dedman and Latour used, examined whether local police officers pursue objectives other than effective policing, such as raising local government revenues from out-of-towners. They examined not only officers' ticketing behavior, but als o how they impose speeding fines.

\section{DATA AND EMPIRICAL STRATEGY}

\section{Sample andDescriptive Statistics}

The original raw data contain 2,001,562 traffic citations issued in Massachusetts between April 2001 and November 2002 The data were collected beginning April 1, 2001, as the Massachusetts legislature passed "An Act Providing for the Collection of the Data Relative to Traffic Stops" in August, 2000. The data include information on the Massachusetts Uniform Citation about motorists, such as race, gender, age, and home town, as well as when they were cite $\mathrm{d}$ and where the vehicles were stopped. All information was based upon officers' reporting (Farrell et al., 2004). We merged the citation-level data with the officer personnel data obtained from the Boston police department. The administrative personnel data include officers' race, gender, and experience on the force. In the merged data, there are only local police officers (i.e. no state police). There are 161,133 matched citations issued by Boston police officers within Boston. ${ }^{7}$ We focus on speeding tickets and warnings, which account for

\footnotetext{
${ }^{7}$ In the literature, there is a concern about using the data on traffic stops on local streets because officers could obtain additional information about drivers from people in the neighborhood and the amount of information
} 
$26 \%$ of all citations, the largest single category. Warnings were computerized for the first two months only, April and May in 2001. We had to delete observations with missing information. First, deleted were 2,041 citations without vehicle speed and 3,128 citations without motorists' race. ${ }^{8}$ We also deleted 1,875 citations where drivers are not white, African-American, or Hispanic and 1,031 citations issued by Asian officers. Finally, for some reasons explained below, we focus on a narrow speed range between 10 and 14. Our sample includes 14,253 speeding tickets and 1,984 warnings.

Table 1 (the first column) shows the descriptive statistics: 1) Motorists are quite young (average age is 36). 2) Almost all are Massachusetts residents while only about 50\% were stopped and given citations in their own neighborhood. 3) There are a small number of commercial-license drivers. 4) About 65\% are male drivers. 5) African-American drivers account for $32 \%$ of tickets, and Hispanics 12\%. According to the 2000 Census, AfricanAmericans account for $25 \%$, and Hispanics $14 \%$ in Boston. If driving habits do not differ by drivers' race (KPT, 2001), this shows that African-American motorists get slightly more tickets. 6) About $32 \%$ of tickets are issued by African-American officers while $10 \%$ by Hispanic officers. In the sample, $24 \%$ of officers are African-Americans and $10 \%$ Hispanic officers. Thus it means that African-American officers issue more tickets per officer. ${ }^{9} 7$ ) About $97 \%$ of tickets are issued by male officers. 8) A majority of tickets (62\%) were issued at a 30 mile speed zone. 9) About 46\% were issued in the morning between 6AM to noon.

might depend on officers' race (Anwar and Fang, 2005). This is, however, unlikely to hap pen when issuing speeding tickets.

${ }^{8}$ The motorist's race is determined by the officer's reporting. This might explain many citations with missing driver race. Also it is possible that the recorded race is different from the actual one. This should not be a problem because, for the purpose of this paper, it is officers' perception about drivers' race that is more relevant.

${ }^{9}$ According to the 2000 Law Enforcement Management and Administrative Statistics (LEMAS), 24\% of officers are African-American and about $6 \%$ are Hispanic nationwide. 
10) Lastly, $57 \%$ of tickets were issued exactly at 10 miles per hour above the posted speed limit.

\section{Clustering of Tickets at 10 above}

As noted before, the most distinctive feature of the data is the clustering of tickets at 10 . Before arguing that officers' speed discounting accounts for this clustering, we exclude the possibility that drivers' æhavior could explain this massive heaping of tickets at this very specific speed. According to the Massachusetts statutory formula, for the first ten miles above the speed limit, the fine is $\$ 75$, and then it rises by ten dollars for each additional mile. Given that the fine amount is constant up to the speed of 10 , it may even be optimal for some motorists to maintain that speed. It is, however, difficult to believe that motorists could control their vehicle speed so delicately, particularly considering the city traffic conditions in Boston. $^{10}$

Furthermore, suppose for a moment that motorists can freely choose vehicle speed. In that case, if the optimal speed were determined by a benefit function which is differentiable and continuous in motorists' characteristics, those characteristics should not have discretely jumped between 10 and nearby speeds. ${ }^{11}$ Also whether to drive at 10 or 11 cannot be an accurately intended choice by motorists. It could rather be randomly determined by a trembling foot of the motorist or the inherent margin of error of a radar gun of the officer. To check this hypothesis, in Table 1, we compare characteristics of motorists cited at 10 and of

\footnotetext{
10 Appendix Figure 1 shows the distribution of reported speeds for speeding tickets issued in the City of Bloomington between 2004 and 2007. There is no notable spike. The fines are $\$ 75$ up to 20 m.p.h. above the limit and, then, increase to $\$ 95$ up to 30 (in addition, some driving points will be accumulated according to the Illinois point system; 5 points up to 10,15 points up to 14 , and so on). Due to the constant fine in a relatively wider range (1-20), there is a weaker incentive for officers to give speed discounting. It seems likely that officers are rarely lenient to motorists who exceed the speed limit by more than 20 m.p.h. The Bloomington data show that the unusual speed distribution in Boston does not result from drivers' behavior.

11 In a working paper, we provided a full-fledged theoretical model analyzing the officers' underreporting decision which can be obtained upon request from the authors.
} 
those cited at a speed level between 11 and 14. Contrary to the hypothesis, we find that some motorist variables are significantly different at very nearby speed levels. Motorists who are ticketed at 10 are older, more likely to be out of town, and less likely to be AfricanAmerican or Hispanic.

If the spike at 10 were totally explained by motorists' driving behavior and if there were no discretionary behavior by officers, then officers' characteristics should not have discretely changed between 10 and nearby speeds. Again, to the contrary, we find that the racial composition of officers significantly differs at very nearby speeds. Among officers who issued tickets at 10,18\% and $12 \%$ are African-American and Hispanic, respectively. On the other hand, among those who issued tickets between 11 and $14,51 \%$ and $8 \%$ are AfricanAmerican and Hispanic. In other words, most of the officers who issued tickets at 10 are white, while a majority of those who issued tickets at a speed between 11 and 14 are AfricanAmerican.

The above findings suggest that the spike at 10 is a consequence of officers' discretionary behavior. There exists anecdotal evidence of officers' discounting the speed. The episode quoted at the beginning of this paper supports our argument. To see this better, first consider a police officer who gains some utility from citing motorists at a speed closer to the actual speed but, at the same time, cares about the fines they will pay. Recall that whether the officer issues tickets at 10 or less does not matter at all in terms of the fines motorists will pay. Thus, for those drivers who actually drove at a speed higher than 10 but were lucky to get speed discounting, 10 would be the most natural speed reported by such officers. ${ }^{12}$ Second, once officers decide to give a break to some drivers, some prominent speed levels may emerge as cognitive reference points. It is a general tendency that people prefer round

\footnotetext{
${ }^{12}$ Alternatively, it is possible that officers can set their speed gun to beep at 10 or higher. Then, the motorists driving under 10 are not stopped, which can explain as to why the histogram abruptly drops below 10 . But this cut-off stopping behavior cannot explain why the speed distribution abruptly drops above that speed.
} 
numbers like 10 and 15 (Johnson et al., 2007). And once such round numbers become prominent in ticketing practice and are established as a social norm, officers may further try to avoid looking too meticulous by citing motorists at non-prominent speed levels such as 11 or 17 when they want to look generous.

Lastly, one may think of the possibility that the clustering arises due to officers' behavior other than s peed discounting, such as over-reporting or random rounding. Note, however, that there is no explicit incentive for officers to over-report the speed to 10 . While over-reporting to 10 does not increase the fine amount and there is no explicit payoff to officers, $\mathbf{t}$ might provoke motorists unnecessarily (this may happen even though motorists have no monetary reason to get upset). We also believe that random rounding should not be prevalent enough to yield such massive clustering of tickets. Suppose that officers round the speed to the nearest round number since such numbers are cognitively less costly to assign. Then, first, officers' and motorists' characteristics should not differ significantly between 10 and nearby speeds, which we have already seen is not true. Second, if some officers do randomly round the speed up or down to the nearest round number, our estimates will be attenuated, making it difficult to discern any systematic disparity.

\section{Proxy Variable}

The above discussion suggests that most of motorists who were ticketed exactly at 10 are likely to be those who actually drove at a higher speed level but received speed discounting. That is, the indicator of whether a motorist gets ticketed at 10 can be a proxy variable for the ticketing officer's leniency toward the motorist.

Formally, et $S$ denote the miles reported above the speed limit and let $S^{*}$ denote the actual speed in miles above the speed limit. Then, we want to know whether the motorist gets speed discounting, that is, whether $S<S^{*}$. For $S \geq 10$, we have: 


$$
\operatorname{Pr}\left(S<S^{*}\right)=\operatorname{Pr}(S=10) \operatorname{Pr}\left(S<S^{*} \mid S=10\right)+\operatorname{Pr}(S>10) \operatorname{Pr}\left(S<S^{*} \mid S>10\right) .
$$

The problem is that the true speed is not observable. Thus, we use the proxy variable of whether $S=10$ or $S>10$. The proxy variable is "exact" if:

$$
\operatorname{Pr}\left(S<S^{*} \mid S=10\right)=1 \text { and } \operatorname{Pr}\left(S<S^{*} \mid S>10\right)=0
$$

The first assumption is violated when there are motorists who were actually traveling at 10 and got ticketed at the exact speed (Type I error). The second asumption is violated when there are motorists who got cited at a speed level above 10 (e.g. 11 or 12) while they drove faster than the speed (Type II error). If any, misclassification bias should be minimal. The case of Type I error should be not significant given the massive spike at 10, virtually no ticket at 9 , and a small number of tickets at 11 . It is likely that most drivers who drove at 10 just get warned. $^{13}$ The latter case should be also ignorable since officers would not presumably use non-prominent speed levels such as 11 or 12 once they decide to be lenient.

To promote the use of the proxy variable further, we restrict our sample to 1) tickets cited at a speed level between 10 and 14 or, more strictly, 2) tickets cited at either 10 or 11 . Due to the massive spike at 10 , the first restricted sample still keeps $55 \%$ of all speeding tickets. There are two rationales for our sample restriction. First, since our purpose is to identify officers' speed discounting as distinctly as possible, we want to minimize motorists' heterogeneity. Especially in the second sample, without speed discounting, motorists should not differ between the two speed levels which differ by only one mile per hour. Thus, in this restricted sample, the inframarginality problem is likely to be, although not completely avoided, minimized. Second, it is reasonable to assume that officers are less likely to give a

\footnotetext{
${ }^{13}$ In Appendix A, following Hausman, Abrevaya, and Scott-Morton (1998), we correct for the bias and find that our main estimates are strengthened.
} 
break to motorists driving 15 or faster. And even if they give speed discounting to these aggressive speeders, the discounted speed should be more likely to be a nearby round number such as 15 or 20 .

Note that the sample restriction drops those tickets whose actual speed is between 10 and 14 but it is reported below 10. This case, however, should be rare given that there are ve ry few tickets under 10.

\section{Rank-Order Test of Anwar and Fang (2006)}

Before we specify our estimation equation, we implement the rank-order test of Anwar and Fang (2006). It is useful since it can be a first litmus test for relative racial bias. In other words, as Anwar and Fang convincingly show, if the test rejects the null hypothesis of no racial bias, then we can be sure of its existence. To apply their test to the question here, i.e. officers' lenient behavior regarding speeding tickets, we modify their behavioral model. In fact, the model is general enough to consider any kind of officers' discretionary behavior. The decision here is whether an officer is lenient enough to give speed discounting to a particular motorist (as opposed to whether to search or not). Following their notations, let $t\left(r_{m}, r_{p}\right)$ denote the cost of a police officer with race $r_{p} \in\{M, W\}$ treating a motorist of race $r_{m} \in\{M, W\}$ harshly. On the other hand, there is a psychological integrity cost $c$ by not reporting the speed that he or she actually observed. We define that an officer is racially prejudiced if $t\left(M ; r_{p}\right) \neq t\left(W ; r_{p}\right)$. Let $G$ denote the event that the motorist will violate the speed limit again in the future when the motorist is treated leniently. ${ }^{14}$ Suppose that the

\footnotetext{
${ }^{14}$ It is uncertain how much officers' ticketing and speed discounting decisions depend on the likelihood of recidivism. It seems reasonable to assume that officers punish recidivists or repeated violators more harshly. But we suspect that they would decide the degree of punishment based on their expectation about recidivism, besides the issue of whether, if any, the practice is legitimate. It is unknown whether it is possible for officers to predict drivers' future behavior.
} 
officer observes a single-dimensional index $\theta \in[0,1]$ that predicts the likelihood of recidivism. ${ }^{15}$ Before observing $\theta$, the officer presumes that a fraction $\pi^{r_{m}} \in[0,1]$ of motorists of race $r_{m}$ will violate the speed limit when they are treated leniently. The index is drawn from a distribution $f_{g}^{r_{m}}$ when the driver is one of those who are believed to speed again and from a distribution $f_{n}^{r_{m}}$ when the driver is one of those who are not believed to speed in the future (i.e. the officer believe that the driver made a mistake this time). After observing $\theta$, the officer updates his belief about $G$ by Bayes' rule:

$$
\operatorname{Pr}\left(G \mid r_{m}, \theta\right)=\frac{\pi^{r_{m}} f_{g}^{r_{m}}(\theta)}{\pi^{r_{m}} f_{g}^{r_{m}}(\theta)+\left(1-\pi^{r_{m}}\right) f_{n}^{r_{m}}(\theta)}
$$

For simplicity, we assume that if the motorist is treated harshly (i.e. no speed discounting), the probability decreases by a factor $\delta \in[0,1]$. The officer's decision is whether to treat the motorist harshly or leniently. The decision problem conditional on ticketing is as follows:

$$
\max \{\underbrace{T-\operatorname{Pr}\left(G \mid r_{m}, \theta\right)-c}_{\text {Lenienttreatment }} ; \underbrace{T-\delta \operatorname{Pr}\left(G \mid r_{m}, \theta\right)-t\left(r_{m} ; r_{p}\right)}_{\text {StrictTreatment }}\}
$$

where $T \in[0,1]$ represents a fixed benefit of ticketing. The officer will treat the motorist harshly if $t\left(r_{m} ; r_{p}\right)-c>(1-\delta) \operatorname{Pr}\left(G \mid r_{m}, \theta\right)$. As Anwar and Fang proved, there exists a threshold $\theta^{*}\left(r_{m} ; r_{p}\right)$ given $c$ and $\delta .{ }^{16}$

Given the above model, we can apply the rank-order test of Anwar and Fang. We also follow the resampling method to ens ure that officers of a given race are assigned to different districts within Boston with the same probabilities. Since the "success rate" is not observable

\footnotetext{
${ }^{15}$ One may think of this index as a weighted sum of the actual speed and an index for the motorist's characteristics, such as a driving record and attitude. They are unobservable to the econometrician.

${ }^{16}$ If the officer's benefit from warning is normalized to zero and if the maximum is less than zero, then the officer will just warn the motorist. The motorist, who looks favorable to the officer, is likely to get warned.
} 
(whether the motorist will not violate the speed limit again due to the strict treatment), we implement the test only for the decision regarding speed discounting. ${ }^{17}$ First, using the Pearson $\chi^{2}$ test, we strongly reject the hypothesis of officers' monolithic behavior for all motorist races. As we see in Table 2, the speed discounting rates differ among officer racial groups for a given group of motorists. In particular, African-American officers are significantly less likely to give speed discounting, while white officers are more likely to be lenient to minority motorists than minority officers are. For all three races of motorists, the $p$ values are less than 0.001 . Second, we also reject the null hypothesis of no racial prejudice. For a given race of motorists, the rank order over the discounting rates across officers' racial groups depends on the race of motorists. Specifically, for white motorists, we cannot reject the equality between white and Hispanic officers (the z-statistic is 0.2), while white officers exhibit higher discounting rates for African-American or Hispanic motorists than AfricanAmerican or Hispanic officers do. The test suggests that at least one racial group of officers is racially prejudiced.

\section{Estimating Racial Disparities}

Having obtained the results from the rank-order test, we further analyze racial disparities in speed discounting. We use the difference-in-difference estimation method (Antonovics and Knight, forthcoming), which is more restrictive than the nonparametric rank-order test. We estimate a Probit model where the dependent variable is the dummy variable of whether a motorist gets ticketed by an officer exactly at 10 , conditional that the motorist gets ticketed and that the reported speed is between 10 and $14:^{18}$

\footnotetext{
${ }^{17}$ Due to the same reason, we cannot apply the KPT test.

${ }^{18}$ An alternative specification is a zero-inflated Poisson model that allows for two different data-generating processes, one for 10 and another for higher speed levels, 11-14. The results are qualitatively t he same.
} 


$$
\begin{aligned}
& \operatorname{Pr}(S=10 \mid X, 10 \leq S \leq 14, T=1)= \\
& \Phi\left[\beta_{0}+\beta_{1}(\text { Motorist })+\beta_{2}(\text { Officer })+\beta_{3}(\text { Context })+\beta_{4}(\text { Racial Interactions })\right]
\end{aligned}
$$

where $T$ is the dummy variable that equals one if a ticket is issued to the motorist. All variables in Table 2 are included in $\mathrm{X}$ motorist characteristics including race (Motorist), officer characteristics including race (Officer), and contextual characteristics, such as time and location (Context). Lastly, of our main interest are interaction terms between officers' and motorists' races (Racial Interactions). The variables are expected to capture racial disparities in speed discounting.

Note that if officers always report the actual speed, then the above equation just accounts for motorists' driving behavior within the speed range from 10 to 14 . If officers' characteristics and the racial interaction terms are uncorrelated with any unobserved motorist characteristics that affect the speeding behavior, both $\beta_{2}$ and $\beta_{4}$ should be insignificant. Since this is critical to our identification, we will check the assumption in more detail later.

There are two race dummy variables for motorists (whites are excluded as the base group). Interpretation of these variables is twofold. On the one hand, the y capture, if any, racial differences in motorists' tendency of speeding. If motorists with a specific race tend to drive faster, they are less likely to get ticketed at 10 , which is the lowest speed within the range from 10 to 14 . On the other hand, the two variables may capture officers' preemptive deterrence efforts or monolithic racial preferences of officers of all races. The first emphasizes the 'schooling drivers' aspect; officers may be stricter with motorists of a specific race if they believe that those motorists will be likely to speed again when treated leniently. Also, dficers might exhibit monolithic racial preferences; in this case, all races of officers would treat the motorists of the mutually most-preferred race more leniently, and he variables for motorists' race would reveal, if any, the officers' preference ordering. 
Two race dummy variables for officers are expected to capture officers' race-specific strictness relative to white officers (the excluded base group). Note that the estimates will be biased (and underestimated in absolute terms) to the extent at which motorists can predict the race of officers they will encounter on their routes. It seems likely in Boston because of the "Same Cop / Same Neighborhood (SC/SN)" policy of the Boston Police Department. ${ }^{19}$ But, we expect that this kind of bias, if any, will be ignorable. First, we control for neighborhood dummy variables. It is not likely that officers are systematically assigned to districts within neighborhoods based on their race and even more unlikely that motorists can predict the race of on-duty officers at precincts and streets within neighborhoods. Second, it is also unlikely that motorists will alter their speed depending on the expected race of officers. To those moderate speeders in our sample, whether there will be an officer on their way regardless of the officer's race should be a more pressing question.

Once we allow that officers' leniency differs by their race, the racial interaction terms are expected to capture different-race officers' disparate treatment of different-race motorists. Ideally, we want to include six different combinations of officers' and motorists' races given three racial groups in our study. It is, however, impossible to estimate all six c oefficients due to perfect collinearity. Thus, we should come up with hypothetical types of racial disparities and, accordingly, impose some parametric constraints (Antonovics and Knight, 2004). In this paper, we include the following four dummy variables; 1) racial mismatch with own-race preferences, 2) minority officer and minority motorist, 3) white motorist and AfricanAmerican officer, and 4) African-American motorist and white officer. These variables are

\footnotetext{
19 Refer to http://www.cityofboston.gov/police/same cop.asp. 'Under SC/SN, the same beat officers are assigned to a neighborhood beat, and will spend no less than $60 \%$ of their shift in that designated beat." There are 11 neighborhoods in Boston. The boundaries of neighborhoods that the police use are slightly different from those of neighborhoods in our data.
} 
motivated by the literature or empirically by our data. All four forms of racial disparities may coexist.

Lastly, we address the sample selection problem. Note that the above Probit model ignores the fact that officers should first decide whether to issue a warning or a ticket (that is, whether $T=1$ ). Recall that warnings were recorded for the first two months of the data, April and May of 2002. Using this subsample, we estimate the Probit selection model:

$$
\begin{aligned}
& \operatorname{Pr}(T=1 \mid \mathrm{X}, 10 \leq S \leq 14)= \\
& \Phi\left[\gamma_{0}+\gamma_{1}(\text { Motorist })+\gamma_{2}(\text { Officer })+\gamma_{3}(\text { Context })+\gamma_{4}(\text { Racial Interactions })\right]
\end{aligned}
$$

We cannot a priori exclude certain variables from the primary Probit model for speed discounting, so we first rely on identification based on functional form assumptions. The model can be estimated by MLE under the assumption of bivariate normality. After trying different specifications for the selection model, we add two squared terms of speed limit and age. In addition, as suggested by Makowsky and Stratmann (forthcoming), we exclude the variable for commercial driver's license from the primary equation. All the excluded variables were insignificant in the primary equation.

\section{EMPIRICAL RESULTS}

\section{Who Gets Speed Discounting from Whom?}

Before proceeding to estimate the Probit model, we look at the racial disparities by using the differences-in-differences (diff-in-diff) estimation method. Table 2 shows the results. First, we find that white officers are more likely to give speed discounting and that white motorists are more likely to receive speed discounting. The diagonal three estimates in the lower right panel are the diff-in-diff estimates. When we separately examine two minority groups, African-Americans and Hispanic s, we find that African-American officers are $6.6 \%$ 
less likely to give speed discounting to African-American motorists and Hispanic officers are $17 \%$ less likely to give speed discounting to Hispanic motorists. When they are put together into one minority group, minority officers are $12 \%$ less likely to give speed discounting to minority motorists. The estimates are all significant at the $1 \%$ level.

Table 3 presents the results from the Probit model. We examine tickets between 10 and 14 in Column (1). In Column (2), the sample is further restricted to tickets cited at 10 and 11 only. We also do a type of placebo test in order to check the validity of our identification strategy of exploiting the clustering of tickets at 10. In Column (3), restricting the sample to tickets between 11 and 14, we estimate the same Probit model with the different dependent variable indicating whether the ticket is cited exactly at 11 . This new dependent variable, which we call a fictitious proxy variable, dos not proxy speed discounting. The model in Column (3) may also revealdifferentials between "the impacts of speed discounting to 10 on those tickets at 11 " and "the impacts of the same speed discounting to 10 on tickets at 12-14." For example, regarding female motorists, if officers are more likely to lower the speed from 11 to 10 than do so from 12 to 10 , we should find relatively fewer tickets issued to female motorists at 11 compared to at 12 . In Column (4), we further restrict the sample to $12-14$ and use the dependent variable of whether the ticket is cited at 12 .

The first notable finding in Columns (1) and (2) is that motorists' characteristics are insignificant except for the number of violations. This is not surprising since in the speed range of $10-14$ or $10-11$, motorists are likely to be homogenous as moderate speeders. The finding about the number of violations may also reflect officers' behavior. Officers would be less likely to give a break in terms of speed discounting to those motorists with multiple violations. Each extra violation decreases the probability of being ticketed at 10 by $4.5 \%$ rather than at a speed level between 11 and 14 .

Unlike motorists' characteristics, officers' characteristics turn out to be mostly significant. First, male officers are significantly (33\%) more likely to issue tickets exactly at 10 . The 
magnitude of this gender gap is substantial. We can even say that speed discounting is basically male officers' behavior. Second, less experienced officers are more likely to give speed discounting. One possible explanation for our findings here is that segments of police officers who can get away more easily with speed discounting commit to it more often. The males constitute the much larger gender group in the police force, and newer, younger officers can easily be forgiven for their mistakes given their relative rookie status.

We find that relative to white officers, African-American and Hispanic officers are significantly less likely to give speed discounting. African-American and Hispanic officers are about $14 \%$ and $9 \%$, respectively, less likely to give speed discounting than white officers. It is interesting to find that those officers who are in a minority status, female, AfricanAmerican, or Hispanic, within the police force are less lenient. These minority segments in the police force cannot easily get away with any mistakes and may feel the need to prove themselves to the largest (and culturally and administratively dominant) group in the police force, namely the while male officers.

Among the racial interaction terms, in Column (1) two variables are significant; one between minority officer and minority motorist and the other between white motorist and African-American officer. Minority officers are $16 \%$ less likely to give speed discounting to minority motorists than white and Hispanic officers are. The gap is larger than that in the diff-in-diff estimate. African-American officers are also $7 \%$ less likely to give speed discounting to white motorists than white and Hispanic officers are. African-American officers are much less lenient to all motorists than other officers; however, they are even less lenient to minority motorists than they are to white motorists.

The results in Column (2) are remarkably similar to those in Column (1). We find that most estimates weaken in magnitude but still remain significant except that the interaction term for African-American officer and white motorist becomes insignificant. 
In Column (3) and (4) using the fictitious proxy variables, as expected, we find that most variables are insignificant. But the dummy variable for African-American officers is significant and opposite in sign (positive) to those in Columns (1) and (2). This means, as explained before, that there are relatively more tickets issued by African-American officers at 11 (or 12) compared to higher speed levels, 12-14 (or 13-14). It shows that white and Hispanic officers tend to discount more tickets that are supposed to be cited at 11 (or 12) than those which are supposed to be cited between 12-14 (or 13-14).

The effect of the speed limit is significantly positive in Column (3) and (4), while it is significantly negative in the first two columns. The negative effect in Columns (1) and (2) is likely to be a result of officers' perception that high speed in itself is a dangerous act and should be curbed more with less discounting as the speed limit the motorists are allowed to travel at increases. The positive effect in Columns (3) and (4) are simply the other side of the coin. It is thus likely to reflect the fact that, taking into account officers' less lenient ticketing in higher speed limit areas, motorists themselves may be reluctart to speed much in those areas, and consequently may get caught and ticketed at the relatively lower speeds in those speed ranges, i.e. at 11 in the $11-14$ range, and at 12 in the $12-14$ range.

As mentioned earlier, to account for officers' endogenous choice of whether to issue a ticket or a warning, we estimate the sample selection model in Table 4. Ticketing behavior should be correlated with speed discounting behavior. From the selection equation, we find that minority officers are more likely to issue tickets rather than warnings to minority motorists. This is consistent with our earlier finding that minority officers are harsher on minority motorists. After correcting for selection, we have a stronger result; minority officers are about $35 \%$ less likely to give speed discounting to minority motorists.

\section{Robustness across Different Subsamples}

We check our finding's robustness to officers' characteristics or motorists' characteristics. Table 5 presents the results for the minority-minority interaction term across different groups 
of officers and motorists. We find that the results are quite consistent across different officer groups. Both experienced and inexperienced minority officers are harsher on minority motorists. Also the result holds regardless of whether officers frequently issue speeding tickets or not (those who issued 100 tickets or more for 20 months versus others), although the result appears stronger among infrequent-ticketing officers.

The results are also qualitatively consistent across different types of motorists. We find, across the board, that minority officers are harsher on minority drivers but the estimates' statistical significance and magnitude are different. First, we find that minority dficers are harsher on male minority motorists, while we find a slightly weaker and insignificant estimate for female motorists. Second, the results are similar between day and night (6PM to 6AM). At night, the disparity becomes stronger. Third, minority officers are harsher on those minority motorists driving relatively old vehicles (aged more than 5 years). The result is not significant and very weak for those with newer vehicles. Lastly, we examine whether the results change across different neighborhoods. We define the neighborhoods with $60 \%$ or more white population as "white neighborhoods" and those with $20 \%$ or more AfricanAmerican or with $20 \%$ or more Hispanic population as "minority neighborhoods." We find that, particularly in the minority neighborhoods, minority officers are harsher on minority motorists. The result is weak and insignificant in white neighborhoods. The lack of significance might be because of relatively few observations of minority officers and minority drivers.

For further robustness check, first, we control for motorists' home zip code. Controlling for zip codes should further reduce unobs erved heterogeneity in motorists' characteristics given the population size of a single zip code area and the degree of socioeconomic heterogeneity. Table 6 shows that our result is strengthened; minority officers are $22 \%$ less likely to give speed discounting to minority motorists. Second, we exclude tickets issued while there were vehicle searches to address the possibility that, as argued in the Related Literature section, 
officers could behave differently when motorists look suspicious. We find that our main result still holds with this sample. Lastly, we examine African-Americans and Hispanics, separately and include four interaction terms (four combinations of AfricanAmerican/Hispanic officers/motorists). The result is consistent across all combinations. It is found that minority officers do not differentiate African-American and Hispanic motorists (that is, African-American and Hispanic motorists are treated equally harshly). The magnitude of the racial bias against minority motorists is larger among Hispanic officers than African-American officers.

\section{Unobservable Motorist Characteristics and Nonrandom Deployment of Officers}

We do not observe all the information about motorists that police officers took into account when they decided whether to give motorists a break or not. The most important unobserved motorist characteristic is their driving record This omitted variable could bias our estimates. The question relevant to our paper is whether minority motorists who get ticketed by minority officers are more likely to have a bad driving record ${ }^{20}$ The concern seems to be legitimate in that minority officers are assigned to neighborhoods in a way that they are statistically more likely to come across such minority motorists. As mentioned before, Boston police officers are likely to be assigned to those districts where more people of their own racial group reside. Thus, minority officers are more likely to meet minority motorists because they more frequently patrol minority residential areas. If minority motorists in minority neighborhoods are more likely to have a bad driving record, then our estimates will be biased.

This should not be a real problem in our study, first of all, because we have already included 10 neighborhood dummy variables. If minority motorists in minority neighborhoods tend to have a bad driving record, both white and minority officers working in those areas

\footnotetext{
${ }^{20}$ Reversely, you might ask why white motorists who get ticketed by minority officers are less likely to have bad driving records. It is a priori uncertain which question is more appropriate to ask.
} 
should be equally likely to meet such bad-driving-record motorists. Furthermore, it seems not true at least in our restricted sample that minority drivers are more likely to be ticketed by minority officers in minority neighborhoods. The sample shows the opposite. In minority neighborhoods, $73 \%$ of minority motorists are ticketed by white officers. In white neighborhoods, about $50 \%$ of minority motorists are ticketed by white officers.

Still our estimates could be biased if minority officers are assigned to specific streets or districts within a neighborhood where minority motorists have a baddriving record compared to white motorists. It is, however, hard to believe that officers are so specifically instructed about their patrol areas. As will be elaborated later in the Discussion section, the finding that minority officers voluntarily concentrate on those particular areas within minority neighborhoods does not contradict our conclusion in this paper.

\section{Unrecorded Stops}

One major disadvantage of the Massachusetts traffic data is that it does not record every vehicle stop. But officers may let certain motorists go even without a written warning, which the econometrician cannot observe at all. This sort of data censoring might bias our estimates for the racial interaction terms, but under very restrictive conditions. Suppose that minority officers stop vehicles and, after finding out minority motorists, only cite those with unobservable negative traits (e.g. with a bad driving record or bad attitude). Also suppose that minority officers do not treat white motorists differentially by such unobservable characteristics and, additionally, that white officers do not use any such criterion regardless of motorists' race. In this case, the estimate for the interaction term between minority officer and minority motorist will be biased and capture unobserved motorist characteristics.

The above scenario suggests that minority officers are more selective in citing drivers than white officers. To check whether it is true, we examine the total number of all citations. The idea is that even though we do not observe the number of motorists an officer let go of, we do 
observe how many tickets the officer issued per day. Also it is reasonable to assume that the more selectively officers choose whom to cite, the fewer citations they will be able to issue tickets per day. This suggests the following estimation equation.

$$
\begin{aligned}
& N_{i j k t}=\alpha_{0}+\alpha_{1}(\text { Motorist Races })+\alpha_{2}(\text { Officer Races })+\alpha_{3}(\text { Racial Interactions }) \\
& +\alpha_{4}(\text { Number of Officers })+(\text { Neighborhood FE })+(\text { Day FE })+u_{i j k t}
\end{aligned}
$$

where $N_{i j k t}$ is the total number of tickets (or all citations including written warnings) issued by officer race group $i$ to motorist race group $j$ in neighborhood $k$ on day $t$. Since there are three racial groups for officers and drivers, respectively, 11 neighborhoods, and 605 days, the maximum number of group-cell observations is 59,895. Each cell is defined by the quadruplet of $i j k t$.

The variable of our main interest here is the interaction term between minority officer and minority motorist. To disentangle it from other confounding effects, we include some control variables. First, we include the dummy variables for motorists' races. Since there are fewer minority motorists, it is not surprising to find fewer tickets being issued to them. Second, we include the number of officers in each group cell since there should be more citations when there are more officers. Lastly, since the volume of traffic and the number of speeding vehicles must vary across time and space, we also add individual neighborhood and daily fixed effects (FE). The neighborhood fixed effects are also important because, as mentioned earlier, we expect that minority officers have a higher chance to encounter minority motorists in minority neighborhoods.

Table 7 shows the results. To the contrary of our concern, we find that minority officers issue more tickets to minority motorists. In an average day, minority officers issue about 0.3 tickes or 0.5 citations (including written warnings) to minority motorists than to white motorists. The same result is found in both white and minority neighborhoods. This is in 
harmony with our previous finding in speed discounting. Overall, the finding that minority officers are harsher on minority motorists is consistent and robust.

\section{DISCUSSION: MINORITY OFFICERS IN THE POLICE FORCE AND VIS-À-VIS MINORITY MOTORISTS}

Our finding is somewhat unusual in that, in the rest of the economics and criminology literature, racial disparities in law enforcement predominantly are (explicitly or implicitly) associaed with discriminatory behavior of white officers against minority people. ${ }^{21}$ To comprehend our general finding, one should ask two complementary questions. First, why do minority officers prefer to treat minority motorists more strictly? Second, is it the minority motorists who provoke minority officers to be strict? The objective of this Discussion section is not to find definite answers, but to search for probable causes.

As to the first question, we need to investigate minority officers' preferences and, more fundamentally, ask why such preferences are formed. First, we notice that minority officers' strictness against minority motorists is not consistent with own-race preferences. It has been found that minority people, particularly AfricanAmericans, have a strong racial identity and own-race preferences (Fryer and Levitt, 2004; Fisman et al., 2008). In-group favoritism is also more theoretically grounded in social psychology since people need to feel positively about themselves and it is more natural(Tajfel and Turner, 1979). ${ }^{22}$ Indeed, the issue in the

\footnotetext{
${ }^{21}$ A few studies did indeed find that minority officers are harsher on minority people in other fields of law enforcement. E.g., Brown and Frank (2006) found that black suspects are more likely to be arrested when the decision maker is a black officer.

${ }^{2}$ As the recent literature in social psychology and economics finds, racial prejudice is likely to be implicit and even unconscious, so it might be revealed only under split-second situations (Price and Wolfers, 2007; Bertrand, Chugh, and Mullainathan, 2005). Plant and Peruche (2005) find that, in computer simulations where they have to take action within seconds, police officers are more likely to mistakenly shoot African-American suspects compared to white ones, although this bias was eliminated after extensive training. But, unlike shooting, ticketing is a conscious prudent behavior. Officers have sufficient time to think about the consequences of their
} 
debate concerning racial profiling is why, if any, cross-race disparities are observed (or felt by the public) and whether officers are racially prejudiced. Thus, it seems that this concept by itself cannot explain our finding (although they might be deeply related, as we will show below).

Instead, we focus on minority officers' status within the police force. Interview -based studies often reveal that minority officers frequently feel racial hostility inside the force and have the day-to-day experience of being an outsider - being constantly tested - within the police subculture: "[black officers] must constantly prove themselves worthy to the many whites who view black Americans as unworthy. As they try to make policing fairer for residents of black communities, their fellow white officers often view them as "radicals"” (Bolton Jr. and Feagin, BF hereafter, 2004: 2). This is also likely to be true for Hispanic officers. Minority officers are often perceived to be not as able as white officers by their colleagues as well as by people (BF: 105). They are also more likely to experience negative social interactions with their supervisors and coworkers (Morris, 1996). Dedman and Latour also reported that minority officers desire to be "accepted" and, for that purpose, they do not want to "go easy" on minority people. An African-American officer said "we are being watched as not only an officer, but also black officers" (BF: 112). We believe that our findings are overall consistent with the hypothesis of the disadvantaged status of minority officers within the police force.

Also, equally plausible, minority officers may want to fix negative stereotypes about their own racial group. This is reasonable because that perception is, no matter whether it is true or not, one of the fundamental causes for their underprivileged status within the force. Alternatively, they might just feel more responsible for or concerned about their own communities' problems. This is in harmony with the casual observation that minority 
community leaders often call for harsh law enforcement because they are more easily blamed than whites. In this case, minority officers' behavior that we found, if that is motivated by their emotional attachment to their own racial group, is not inconsistent with own-race preference and positive racial identity.

Lastly, regarding the second question posed in the beginning, it is conceivable that our finding is caused by drivers' behavior in the first place. Looking at drivers' side is somewhat unusual; the racial profiling literature attempts to explain any observedracial disparities by officers' behavior. ${ }^{23}$ This approach is reasonable in that it is officers who make decisions and take actions: the relationship between officers and the public is hierarchical so people are not in a position to argue against officers, particularly in the situation like vehicle searches. In the case of minor offenses such as moderate speeding, it seems plausible that the stopped drivers might disagree with officers, complain, and ask for harsh punishment. ${ }^{24}$ The question is why minority motorists are more likely to provoke minority officers despite such behavior's adverse consequence on themselves.

The defiance behavior should not be optimal unless we restrict drivers' preferences. However, indeed, it seems possible that minority drivers have different preferences about minority officers (or one might say motorists' racial prejudice). Simply, it is likely that minority motorists argue against minority officers because they feel closer to officers of their race, and this more comfortable position may prompt them to dare talking back to such officers. Somewhat ironically, this cultural closeness might provoke officers' unfavorable reactions. Of course, we should keep in mind that officers, being professional, should not be affected emotionally by drivers' behavior if it is irreleva nt to efficient or fair law enforcement.

\footnotetext{
${ }^{23}$ Anwar and Fang (2006) point out the possibility that motorists' behavior depends on the race of officers.

${ }^{24}$ Ridgeway (2006) found that black motorists tend to have longer duration of vehicle stop although it is unknown whether it is due to officers' intentional tardiness or motorists' complaining.
} 
Alternatively, it is possible that minority drivers feel disappointed or even betrayed when they are harshly treated by officers of their own race. "[S]ome members of black communities perceive them to be traitors" and "[a] large proportion of black police officers reported that they commanded more respect from white citizens than from black citizens; further, most of these officers also reported that they did not live in the community they worked" (BF). Minority officers are therefore dissociated from their own community not only because they are police officers, but also because they belong to a different socioeconomic class (Leinen, 1984, p. 177).

\section{CONCLUSION}

Although "speed discounting" has always been a very prevalent phenomenon, it has never been addressed before in the growing economics and criminology literature regarding discretionary behavior of police officers. Studying speed discounting and finding out which groups of officers commit to that is therefore a new strand of research.

Racial disparities in policing, however, have been studied extensively in the stop-andsearch and ticketing literature. Studying racial disparities in the speed-discounting context, however, adds a new and, to a large extent, unexpected dimension to the racial bias literature. One might consider racial disparities in speeding tickets as a relatively minor issue compared to those in vehicle searches. The issue we examined in this paper is, however, something more relevant to people everyday. A lso, perhaps, it is a unique context to study interactions between officers and a fairly large number of motorists.

A natural question is whether there should be any public policy to fix this problem. The main problem appears to be that the police departments are dominated by white male officers (and their culture) who can use their discretion liberally without any consequences. It also seems that the minority groups in the police force have to do certain things to be accepted by this dominant group of white-male police officers. What is happening in terms of traffic 
ticketing is not a mutual racial discrimination between different races or even against one particular race by all races. Instead, it is the minorities - be it the ones in the police force or on the streets as drivers - who seem to suffer at each other's hands. The ticketing disparity is simply the consequence or symptom of the current social structure and culture. One perhaps needs to support the current effort of promoting rac ial diversity in the police force.

The existing culture and institutional structure, however, may persist for a long time. What can be done to treat the symptom - i.e. the minority-to-minority racial disparity in traffic ticketing - in the meantime? The use of speed cameras, which are widespread in the other parts of the world and are color-blind in nature, may not only be effective in curbing speeding and reducing vehicle accidents, ${ }^{25}$ but may also restore the trust of the minorities in the traffic ticketing system; this may be a small step by itself, but it can potentially trigger additional steps in various other racial issues involving minorities.

To shed better light on this issue, one also needs to collect more data that on interactions between officers and motorists during ticketing stops ${ }^{26}$ as well as on those motorists' driving records - not to mention more data from other parts of the country where the racial composition within the population and the police force favor different types of minorities more.

${ }^{25}$ Speed cameras also substantially reduce speeding violations and, as a result, injury crashes. Retting and Farmer (2003) report that, within six months after mobile speed cameras were employed in the District of Columbia, the proportion of motorists exceeding speed limits by more than 10 m.p.h. declined by $82 \%$. Further, Insurance Institute for Highway Safety (1991) reported that, in Garland, Utah, highly publicized speed cameras in a 20 m.p.h. school zone reduced the average speed from 36 to 22 m.p.h. In the U.S., speed cameras have been used in 35 jurisdictions and red-light cameras have been used in 300 jurisdictions throughout 22 states (http://www.iihs.org/research/topics/auto enforce cities.html).

${ }^{26}$ For example, the Miami-Dade Police Department Racial Profiling Study used trained observers to ride with police officers. This data collection method would deliver more lively information about police-driver interactions while it might be intrusive as well as costly. 


\section{References:}

[1] Antonovics, Kate L. and Brian G. Knight. 2004. “A New Look at Racial Profiling: Evidence from the Boston Police Department." NBER Working Paper No. 10634 (forthcoming at Review of Economics and Statistics).

[2] Anwar, Shamena and Hanming Fang. 2006. "An Alternative Test of Racial Prejudice in Motor Vehicle Searches: Theory and Evidence.” American Economic Review, 96(1), pp. 127-151.

[3] Bertrand, Marianne, Dolly Chugh, and Sendhil Mullainathan. 2005. "Implicit Discrimination.” American Economic Review Papers and Proceedings, 9498.

[4] Blalock, Garrick, Jed DeVaro, Stephanie Leventhal, and Daniel H. Simon. 2007. "Gender Bias in Power Relationships: Evidence from Police Traffic Stops" ILR Collection Working Papers, Cornell University.

[5] Bolton Jr., Kenneth and Joe R. Feagin. 2004. Black in Blue: African-American Police Officers and Racism. New York: Routledge.

[6] Brown, Robert and James Frank. 2006. "Race and Officer Decision Making: Examining Differences in Arrest Outcomes between Black and White Officers.” Justice Quarterly, 23(1): 96-126.

[7] Clarke, Ronald V. 1996. "The Distribution of Deviance and Exceeding the Speed Limit.” The British Journal of Criminology, 36(2): 269-181.

[8] Close, Billy R. and Patrick L. Mason. 2007. "Searching for Efficient Enforcement: Officer Characteristics and Racially Biased Policing." Review of Law \& Economics, Vol. 3, No. 2, Article 5. (http://www.bepress.com/rle/vol3/iss2/art5)

[9] Correll, Joshua, Bernadette Park, Charles M. Judd, Bernd Wittenbrink, and Melody S. Sadler. 2007. "Across the Thin Blue Line: Police Officers and Racial Bias in the Decision to Shoot.” Journal of Personality \& Social Psychology, 92(6): 1006-1023. 
[10] Dedman, Bill and Francie Latour. 2003. "Speed Trap: Who Gets a Ticket and Who Gets a Break?" The Boston Globe.

(http://www.boston.com/globe/metro/packages/tickets/072003.shtml) (http://www.boston.com/globe/metro/packages/tickets/072003b.shtml) (http://www.boston.com/globe/metro/packages/tickets/072003c.shtml).

[11] Department of Justice. 2001. Policing and Homicide: Justifiable Homicide by Police, Police Officers Murdered by Felons (NCJ 180987). Washington D.C. Bureau of Justice Statistics.

[12] Donohue III, John J. and Steven D. Levitt. 2001. "The Impact of Race on Policing and Arrests." Journal of Law and Economics, vol. XLIV: 367-394.

[13] Engel, Robin S. and Jennifer M. Calnon. 2004. "Comparing Benchmark Methodologies for Police-Citizen Contacts: Traffic Stop Data Collection for the Pennsylvania State Police.” Police Quarterly, 7(1), pp. 97-125.

[14] Farrell, Amy, Jack McDevitt, Lisa Bailey, Carsten Andresen, and Erica Pierce. 2004. "Massachusetts Racial and Gender Profiling Study," Northeastern University, Institute on Race and Justice (http://www.mass.gov/Eeops/docs/eops/Racial_and_Gender_Profiling_Study.pdf)

[15] Fisman, Raymond, Sheena S. Iyengar, Emir Kamenica, and Itamar Simonson. 2008. “Racial Preferences in Dating.” Review of Economic Studies, 75: 117-132.

[16] Fryer, Roland G. and Steven D. Levitt. 2004. "The Causes and Consequences of Distinctively Black Names.” Quarterly Journal of Economics, 119: 767-805.

[17] Grogger, Jeffrey and Greg Ridgeway. 2006. "Testing for Racial Profiling in Traffic Stops from behind a Veil of Darkness.” Journal of the American Statistical Association, 101(475), pp. 878-887. 
[18] Hausman, Jerry A., Jason Abrevaya, and F.M. Scott-Morton. 1998. "Misclassification of the Dependent Variable in a Discrete-Response Setting." Journal of Econometrics, 87: 239-269.

[19] Insurance Institute for Highway Safety. 1991. Innovative Technology Is Helping Police Enforce Speed Limits across the Nation. Status Report, 26 (8), 6. Arlington, VA.

[20] Johnson, Edward, Nicole B. Johnson, and Devin Shanthikumar. 2007. "Round Numbers and Security Returns.” Unpublished Working Paper.

[21] Knowles, John, Nicola Persico, and Petra Todd. 2001. "Racial Bias in Motor Vehicle Searches: Theory and Evidence.” Journal of Political Economy, 109(1), pp. 203-232.

[22] Lamberth, John. 1996. A Report to ACLU. New York: American Civil Liberties Union. (http://www.aclu.org/court/lamberth.html).

[23] Lawpoolsri, Saranath, Li Jingyi, and Elisa Braver. 2007. "Do Speeding Tickets Reduce the Likelihood of Receiving Subsequent Speeding Tickets? A Longitudinal Study of Speeding Violators in Maryland.” Traffic Injury Prevention, 8(1): 26-34.

[24] Leinen, Stephen. 1984. Black Police, White Society. New York: New York University Press.

[25] Makowsky, Michael and Thomas Stratmann. forthcoming. "Determinants of Traffic Citations: Political Economy at Any Speed." American Economic Review .

[26] McConnell, E. H. and A. R. Scheidegger. 2001. "Race and Speeding Citations: Comparing Speeding Citations Issued by Air Traffic Officers with Those Issued by Ground Traffic Officers." Presented at the annual meeting of the Academy of Criminal Justice Sciences, Washington D.C.

[27] Morris, Anne. 1996. "Gender and Ethnic Differences in Social Constraints Among a Sample of New York City Police Officers." Journal of Occupational and Health Psychology, 1(2), 224-235. 
[28] National Highway Traffic Safety Administration. 2002. National Survey of Speeding and Other Unsafe Driving Actions, Volume II: Driver Attitudes and Behavior, U.S. Department of Transportation.

[29] Persico, Nicola. forthcoming. "Racial Profiling? Detecting Bias Using Statistical Evidence." Annual Review of Economics.

[30] Plant, E. Ashby, and B. Michelle Peruche. 2005. "The Consequences of Race for Police Officers’ Responses to Criminal Suspects.” Psychological Science, 16, 180-183.

[31] Price, Joseph and Justin Wolfers. 2007. "Racial Discrimination Among NBA Referees." forthcoming at Quarterly Journal of Economics.

[32] Retting, Richard A. and Charles M. Farmer. 2003. "Evaluation of Speed Camera Enforcement in the District of Columbia.” Transportation Research Record, 1830, 34 37.

[33] Ridgeway, Greg. 2006. "Assessing the Effect of Race Bias in Post-traffic Stop Outcomes Using Propensity Scores.” Journal of Quantitative Criminology, 22(1), pp. $1-29$.

[34] Riley, Jack and Greg Ridgeway. 2004. "Commentary: Measuring Racial Profiling by Police.” June Issue, Law Enforcement News.

[35] State of New Jersey v. Soto. 1996. A734A. 2d 350 (N.J. Super. Ct. Law Div. 1996).

[36] Tajfel, Henri and John Turner. 1979. “An Integrative Theory of Intergroup Conflict.” In W.G. Austin and S. Worchel (Eds.), The Social Psychology of Intergroup Relations, Monterey, CA: Brokks/Cole.

[37] Tomaskovic-Devey, Donald, Marcinda Mason, and Matthew Zingraff. 2004. "Looking for the Driving While Black Phenomena: Conceptualizing Racial Bias Processes and Their Associated Distributions." Police Quarterly, 7(1): 3-29. 


\section{Appendix A. Misclassification Bias}

As we explained in the paper, our proxy variable classifies those motorists who actually traveled exactly at 10 as those who received speed discounting. For the true variable for speed discounting, $1\left(S<S^{*}\right)$, we use $1(S=10)$ as the proxy variable given the speed range from 10 to 14. In this Appendix, we follow Hausman, Abrevaya, and Scott-Morton (1998) and correct the misclassification bias. If we assume that once officers decide to give speed discounting, they do not cite a speed level between 11 and 14 (that is, we assume that $\left.\operatorname{Pr}\left(S<S^{*} \mid 11 \leq S \leq 14\right)=0\right)$, then the misclassification probability is:

$$
\alpha=\operatorname{Pr}\left(S=S^{*} \mid S=10\right) \text {. }
$$

The expected value of the observed proxy variable is

$$
E(1(S=10) \mid 10 \leq S \leq 14, X)=\alpha+(1-\alpha) \Phi(X \beta)
$$

We can estimate $\alpha$ and $\beta$ with the maximum likelihood estimation under the normality assumption. We found that the misclassification probability is about 0.13 and significant at the $1 \%$ significance level. The estimates $\beta$ are, however, similar to our previous results. The marginal effect of the interaction term between minority officer and minority motorist is estimated as -0.174 , also significant at the $1 \%$ significance level. The other racial interaction terms turn out to be insignificant. 
Table 1. Descriptive Statistics of Speeding Tickets

\begin{tabular}{|c|c|c|c|c|}
\hline & All & 10 & $11-14$ & Mean Diff. \\
\hline \multicolumn{5}{|l|}{ Motorist Characteristics } \\
\hline Age & $\begin{array}{c}36.37 \\
(12.37)\end{array}$ & $\begin{array}{c}36.80 \\
(12.49)\end{array}$ & $\begin{array}{r}35.79 \\
(12.19)\end{array}$ & $\mathrm{p}<0.01$ \\
\hline In Town & $\begin{array}{r}0.489 \\
(0.500)\end{array}$ & $\begin{array}{c}0.454 \\
(0.498)\end{array}$ & $\begin{array}{r}0.534 \\
(0.499)\end{array}$ & $\mathrm{p}<0.01$ \\
\hline In State & $\begin{array}{c}0.939 \\
(0.240)\end{array}$ & $\begin{array}{c}0.936 \\
(0.245)\end{array}$ & $\begin{array}{c}0.942 \\
(0.233)\end{array}$ & $p=0.13$ \\
\hline $\begin{array}{l}\text { Commercial Driver } \\
\text { License }\end{array}$ & $\begin{array}{c}0.023 \\
(0.150)\end{array}$ & $\begin{array}{c}0.023 \\
(0.149)\end{array}$ & $\begin{array}{c}0.023 \\
(0.150)\end{array}$ & $\mathrm{p}=0.91$ \\
\hline Number of Violations & $\begin{array}{r}1.330 \\
(0.548)\end{array}$ & $\begin{array}{l}1.325 \\
(0.549)\end{array}$ & $\begin{array}{r}1.336 \\
(0.547)\end{array}$ & $\mathrm{p}=0.26$ \\
\hline Male & $\begin{array}{c}0.645 \\
(0.479)\end{array}$ & $\begin{array}{c}0.650 \\
(0.477)\end{array}$ & $\begin{array}{c}0.638 \\
(0.481)\end{array}$ & $\mathrm{p}=0.14$ \\
\hline African-American & $\begin{array}{c}0.323 \\
(0.468)\end{array}$ & $\begin{array}{c}0.301 \\
(0.459)\end{array}$ & $\begin{array}{c}0.353 \\
(0.478)\end{array}$ & $\mathrm{p}<0.01$ \\
\hline Hispanic & $\begin{array}{c}0.121 \\
(0.326)\end{array}$ & $\begin{array}{c}0.103 \\
(0.304)\end{array}$ & $\begin{array}{r}0.145 \\
(0.352) \\
\end{array}$ & $\mathrm{p}<0.01$ \\
\hline \multicolumn{5}{|l|}{ Officer Characteristics } \\
\hline Officer Experience & $\begin{array}{c}10.61 \\
(5.382)\end{array}$ & $\begin{array}{c}9.006 \\
(4.434)\end{array}$ & $\begin{array}{c}12.74 \\
(5.776)\end{array}$ & $\mathrm{p}<0.01$ \\
\hline Male & $\begin{array}{r}0.975 \\
(0.157)\end{array}$ & $\begin{array}{c}0.988 \\
(0.109)\end{array}$ & $\begin{array}{r}0.957 \\
(0.203)\end{array}$ & $\mathrm{p}<0.01$ \\
\hline African-American & $\begin{array}{r}0.319 \\
(0.466)\end{array}$ & $\begin{array}{c}0.177 \\
(0.382)\end{array}$ & $\begin{array}{c}0.508 \\
(0.500)\end{array}$ & $\mathrm{p}<0.01$ \\
\hline Hispanic & $\begin{array}{c}0.105 \\
(0.306) \\
\end{array}$ & $\begin{array}{c}0.120 \\
(0.324) \\
\end{array}$ & $\begin{array}{r}0.085 \\
(0.279) \\
\end{array}$ & $\mathrm{p}<0.01$ \\
\hline \multicolumn{5}{|l|}{ Citation Characteristics } \\
\hline Speed Limit & $\begin{array}{r}31.49 \\
(4.816)\end{array}$ & $\begin{array}{c}31.55 \\
(5.153)\end{array}$ & $\begin{array}{r}31.40 \\
(4.325)\end{array}$ & $p=0.06$ \\
\hline Morning (6AM-Noon) & $\begin{array}{r}0.460 \\
(0.498)\end{array}$ & $\begin{array}{c}0.535 \\
(0.499)\end{array}$ & $\begin{array}{r}0.360 \\
(0.480)\end{array}$ & $\mathrm{p}<0.01$ \\
\hline Afternoon (Noon-6PM) & $\begin{array}{r}0.281 \\
(0.449)\end{array}$ & $\begin{array}{c}0.251 \\
(0.434)\end{array}$ & $\begin{array}{r}0.320 \\
(0.466)\end{array}$ & $\mathrm{p}<0.01$ \\
\hline Evening (6PM-midnight) & $\begin{array}{r}0.206 \\
(0.404)\end{array}$ & $\begin{array}{c}0.139 \\
(0.346)\end{array}$ & $\begin{array}{c}0.295 \\
(0.456)\end{array}$ & $\mathrm{p}<0.01$ \\
\hline Speed above the Limit & $\begin{array}{r}11.09 \\
(1.442)\end{array}$ & & & \\
\hline No. of Observations $=$ & 14,253 & 8,130 & 6,123 & \\
\hline
\end{tabular}

Note: STD stands for standard deviation. Officers' experience is measured in terms of years on the force. The last column shows $\mathrm{p}$-values for mean equality tests between characteristics of tickets cited at 10 and those between 11 and 14 . 
Table 2. Differences in Differences: $\operatorname{Pr}(S=10 \mid 10 \leq S \leq 14, T=1)$

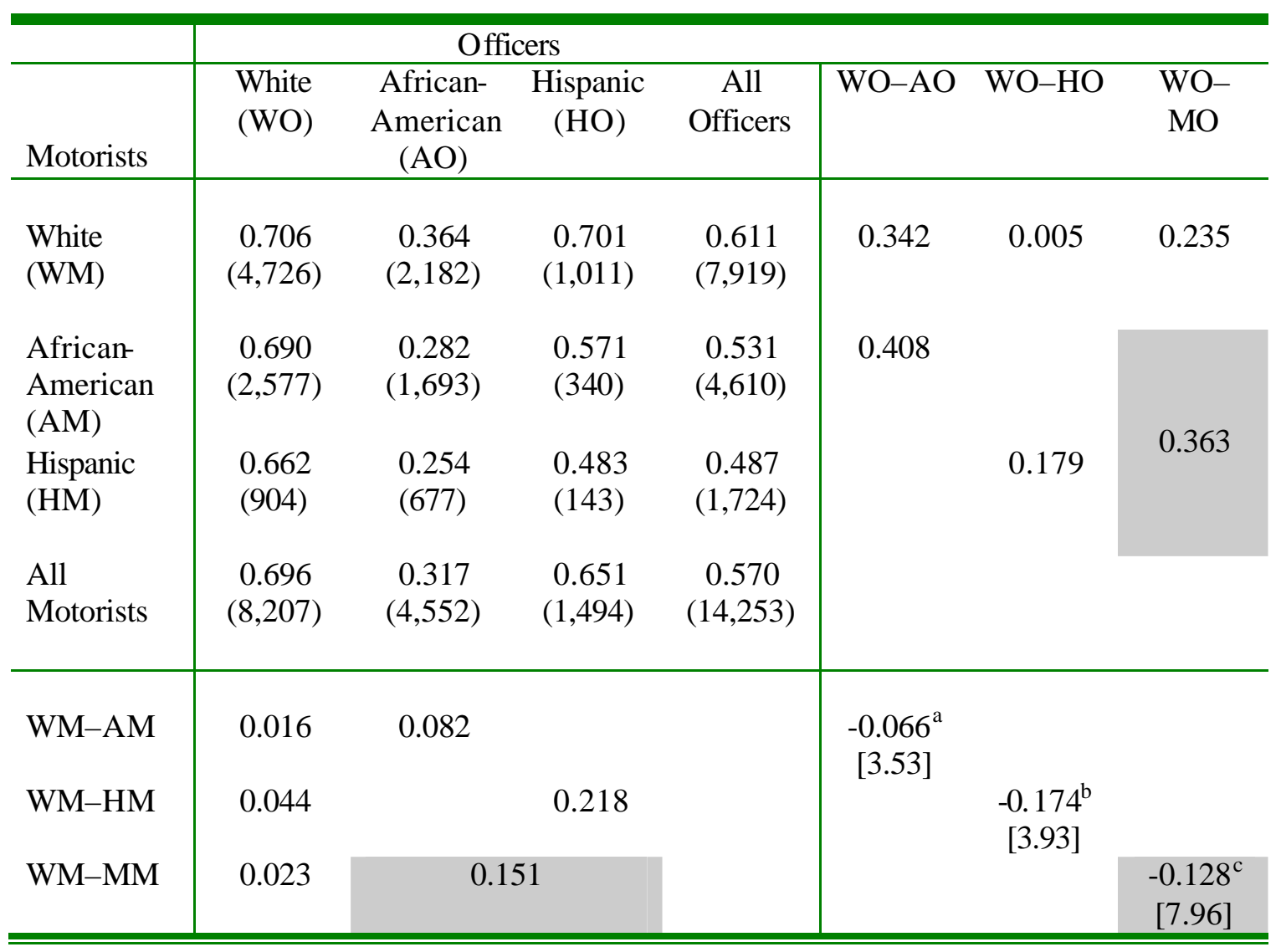

Note: MO stands for minority officers, and MM stands for minority motorists. The number of observations is displayed in parentheses. The absolute value of t-statistic is presented in brackets.
a: (WM-AM) - (WO-AO).
b: (WM-HM) - (WO-HO).
c: $(\mathrm{WM}-\mathrm{MM})-(\mathrm{WO}-\mathrm{MO})$. 
Table 3. Probit Model for Speed Discounting

\begin{tabular}{|c|c|c|c|c|}
\hline \multirow[b]{4}{*}{ Sample Speed Range } & \multirow[t]{2}{*}{ (1) } & \multirow[t]{2}{*}{ (2) } & \multirow{2}{*}{\multicolumn{2}{|c|}{$\begin{array}{c}(3) \\
\text { Fictitious Proxy Variables }\end{array}$}} \\
\hline & & & & \\
\hline & $\operatorname{Pr}(\mathrm{S}=10)$ & $\operatorname{Pr}(\mathrm{S}=10)$ & $\operatorname{Pr}(S=11)$ & $\operatorname{Pr}(S=12)$ \\
\hline & $10-14$ & 10-11 & 11-14 & $12-14$ \\
\hline \multirow[t]{2}{*}{ Speed Limit } & $-0.011 * * *$ & $-0.006 * * *$ & $0.008 * * *$ & $0.006 * * *$ \\
\hline & $(0.001)$ & $(0.001)$ & $(0.002)$ & $(0.002)$ \\
\hline \multirow[t]{2}{*}{ Age } & 0.000 & 0.000 & 0.001 & -0.000 \\
\hline & $(0.000)$ & $(0.000)$ & $(0.000)$ & $(0.001)$ \\
\hline \multirow[t]{2}{*}{ In Town } & -0.007 & -0.007 & 0.017 & 0.006 \\
\hline & $(0.010)$ & $(0.007)$ & $(0.012)$ & $(0.016)$ \\
\hline \multirow[t]{2}{*}{ In State } & 0.012 & 0.001 & 0.011 & 0.033 \\
\hline & $(0.019)$ & $(0.014)$ & $(0.023)$ & $(0.030)$ \\
\hline \multirow[t]{2}{*}{ Commercial Driver License } & -0.006 & 0.003 & -0.014 & 0.053 \\
\hline & $(0.030)$ & $(0.021)$ & $(0.035)$ & $(0.048)$ \\
\hline \multirow[t]{2}{*}{ Male Motorist } & 0.078 & 0.037 & -0.023 & -0.003 \\
\hline & $(0.060)$ & $(0.040)$ & $(0.050)$ & $(0.071)$ \\
\hline \multirow[t]{2}{*}{ Male Officer } & $0.335 * * *$ & $0.191 * * *$ & 0.033 & 0.026 \\
\hline & $(0.041)$ & $(0.059)$ & $(0.038)$ & $(0.059)$ \\
\hline Male Motorist * & -0.090 & -0.022 & -0.015 & -0.006 \\
\hline Male Officer & $(0.060)$ & $(0.036)$ & $(0.051)$ & $(0.073)$ \\
\hline \multirow[t]{2}{*}{ Years on the Force } & $-0.024 * * *$ & $-0.009 * * *$ & -0.001 & $-0.003 *$ \\
\hline & $(0.001)$ & $(0.001)$ & $(0.001)$ & $(0.002)$ \\
\hline \multirow[t]{2}{*}{ African-American Motorist } & 0.039 & 0.011 & 0.025 & 0.066 \\
\hline & $(0.032)$ & $(0.021)$ & $(0.036)$ & $(0.046)$ \\
\hline \multirow[t]{2}{*}{ Hispanic Motorist } & -0.006 & -0.017 & 0.034 & 0.045 \\
\hline & $(0.035)$ & $(0.027)$ & $(0.045)$ & $(0.056)$ \\
\hline \multirow[t]{2}{*}{ African-American Officer } & $-0.136 * * *$ & $-0.138 * * *$ & $0.127 * * *$ & $0.140 * *$ \\
\hline & $(0.036)$ & $(0.037)$ & $(0.047)$ & $(0.059)$ \\
\hline \multirow[t]{2}{*}{ Hispanic Officer } & $-0.091 * * *$ & $-0.057 *$ & 0.026 & -0.018 \\
\hline & $(0.034)$ & $(0.031)$ & $(0.045)$ & $(0.054)$ \\
\hline \multirow[t]{2}{*}{ Racial Mismatch } & 0.009 & 0.018 & -0.021 & 0.044 \\
\hline & $(0.028)$ & $(0.019)$ & $(0.031)$ & $(0.042)$ \\
\hline Minority Motorist * & $-0.164 * * *$ & $-0.084 *$ & 0.019 & -0.003 \\
\hline Minority Officer & $(0.045)$ & $(0.043)$ & $(0.056)$ & $(0.070)$ \\
\hline African-American Motorist * & -0.014 & -0.022 & 0.029 & $-0.084 *$ \\
\hline White Officer & $(0.035)$ & $(0.027)$ & $(0.045)$ & $(0.051)$ \\
\hline White Motorist $*$ & $-0.074 * *$ & -0.046 & 0.040 & -0.021 \\
\hline African-American Officer & $(0.035)$ & $(0.029)$ & $(0.044)$ & $(0.054)$ \\
\hline \multirow[t]{2}{*}{ \# Violations } & $-0.045^{* * *}$ & $-0.011 *$ & 0.015 & 0.011 \\
\hline & $(0.009)$ & $(0.006)$ & $(0.010)$ & $(0.013)$ \\
\hline \multirow[t]{2}{*}{ Morning } & $-0.267 * * *$ & $-0.108 * * *$ & 0.023 & $0.102 * *$ \\
\hline & $(0.022)$ & $(0.017)$ & $(0.035)$ & $(0.050)$ \\
\hline
\end{tabular}




\begin{tabular}{lcccc} 
Afternoon & $-0.302 * * *$ & $-0.126 * * *$ & -0.020 & $0.151^{* * *}$ \\
& $(0.022)$ & $(0.023)$ & $(0.033)$ & $(0.050)$ \\
Evening & $-0.329 * * *$ & $-0.159 * * *$ & -0.009 & $0.112^{* *}$ \\
& $(0.022)$ & $(0.028)$ & $(0.034)$ & $(0.051)$ \\
\hline Day of the Week & Yes & Yes & Yes & Yes \\
Neighborhood & Yes & Yes & Yes & Yes \\
\hline Number of Observations & 14,253 & 9,439 & 6,123 & 4,814 \\
Pseudo R-squared & 0.156 & 0.193 & 0.0362 & 0.027 \\
\hline \hline
\end{tabular}

Note: Robust standard errors are in parentheses, * significant at $10 \% ; * *$ significant at 5\%; *** significant at $1 \%$. Marginal effects are calculated at the sample means. Included are a constant term, six dummy variables for Day of the Week, and 10 dummy variables for Neighborhood. 
Table 4. Heckman Probit Selection Model

\begin{tabular}{|c|c|c|}
\hline Dependent Variables & $\begin{array}{c}(1) \\
\text { Selection } \\
1(\mathrm{~T}=1)\end{array}$ & $\begin{array}{c}(2) \\
\text { Speed Discounting } \\
1(\mathrm{~S}=10 \mid \mathrm{T}=1)\end{array}$ \\
\hline Speed Limit & $\begin{array}{l}-0.153 * * * \\
(0.024)\end{array}$ & $\begin{array}{c}-0.008 * * \\
(0.004)\end{array}$ \\
\hline Speed Limit Squared & $\begin{array}{l}0.003 * * * \\
(0.000)\end{array}$ & \\
\hline Age & $\begin{array}{l}0.013 * * * \\
(0.004)\end{array}$ & $\begin{array}{c}0.0004 \\
(0.0012)\end{array}$ \\
\hline Age Squared & $\begin{array}{l}-0.0002 * * * \\
(0.00004)\end{array}$ & \\
\hline In Town & $\begin{array}{l}-0.051 * * \\
(0.021)\end{array}$ & $\begin{array}{c}0.008 \\
(0.031)\end{array}$ \\
\hline In State & $\begin{array}{l}-0.057 \\
(0.041)\end{array}$ & $\begin{array}{l}0.146 * * * \\
(0.057)\end{array}$ \\
\hline Commercial Driver License & $\begin{array}{l}-0.180 * * * \\
(0.046)\end{array}$ & \\
\hline Male Motorist & $\begin{array}{c}0.104 \\
(0.142)\end{array}$ & $\begin{array}{c}0.157 \\
(0.177)\end{array}$ \\
\hline Male Officer & $\begin{array}{l}-0.171 \\
(0.121)\end{array}$ & $\begin{array}{l}0.380 * * * \\
(0.144)\end{array}$ \\
\hline Male Motorist $*$ Male Officer & $\begin{array}{l}-0.082 \\
(0.146)\end{array}$ & $\begin{array}{l}-0.192 \\
(0.170)\end{array}$ \\
\hline Years on the Force & $\begin{array}{l}0.008 * * * \\
(0.002)\end{array}$ & $\begin{array}{l}-0.014 * * * \\
(0.004)\end{array}$ \\
\hline African-American Motorist & $\begin{array}{l}-0.215^{* * *} \\
(0.067)\end{array}$ & $\begin{array}{l}0.205^{* *} \\
(0.092)\end{array}$ \\
\hline Hispanic Motorist & $\begin{array}{c}-0.166^{* *} \\
(0.075)\end{array}$ & $\begin{array}{c}0.163^{*} \\
(0.088)\end{array}$ \\
\hline African-American Officer & $\begin{array}{c}0.074 \\
(0.091)\end{array}$ & $\begin{array}{r}-0.133 \\
(0.100)\end{array}$ \\
\hline Hispanic Officer & $\begin{array}{c}0.142 \\
(0.094)\end{array}$ & $\begin{array}{r}-0.006 \\
(0.101)\end{array}$ \\
\hline Racial Mismatch & $\begin{array}{l}0.141^{*} \\
(0.077)\end{array}$ & $\begin{array}{l}-0.087 \\
(0.083)\end{array}$ \\
\hline Minority Motorist * Minority Officer & $\begin{array}{l}0.269 * * \\
(0.113)\end{array}$ & $\begin{array}{l}-0.351 * * * \\
(0.135)\end{array}$ \\
\hline $\begin{array}{l}\text { African-American Motorist * } \\
\text { White Officer }\end{array}$ & $\begin{array}{c}0.106 \\
(0.094)\end{array}$ & $\begin{array}{l}-0.002 \\
(0.114)\end{array}$ \\
\hline White Motorist $*$ & -0.053 & 0.048 \\
\hline African-American Officer & $(0.088)$ & $(0.095)$ \\
\hline Morning & $0.153 * * *$ & $-0.299 * * *$ \\
\hline
\end{tabular}




\begin{tabular}{lcc} 
& $(0.042)$ & $(0.060)$ \\
Afternoon & $0.084^{*}$ & $-0.231 * * *$ \\
& $(0.043)$ & $(0.064)$ \\
Evening & 0.072 & $-0.282^{* * *}$ \\
& $(0.047)$ & $(0.070)$ \\
Rho & & $-0.438^{*}$ \\
& & $(0.225)$ \\
\hline Day of the Week & Yes & Yes \\
Neighborhood & Yes & Yes \\
Number of Observations $=$ & 3,076 & 1,285 \\
\hline \hline
\end{tabular}

Note: Robust standard errors are in parentheses, * significant at $10 \%$; ** significant at 5\%; *** significant at $1 \%$. In both columns, marginal effects, except for Rho, are calculated at the sample means. The sample is restricted to April and May in 2001 when warnings were recorded. 
Table 5. Results for Minority Officers and Minority Motorists acro ss Subsamples

\begin{tabular}{|c|c|c|c|c|}
\hline & Subsample 1 & & Subsample 2 & \\
\hline Officers' Gender & $\begin{array}{c}\text { Male } \\
\text { Officers }\end{array}$ & $\begin{array}{l}-0.158 * * * \\
(0.046)\end{array}$ & $\begin{array}{l}\text { Female } \\
\text { Officers }\end{array}$ & n.a. \\
\hline & & {$[13,896]$} & & [357] \\
\hline Years on the Force & $=5$ Years & $\begin{array}{l}-0.326 * \\
(0.177) \\
{[1,391]}\end{array}$ & 5 Years $<$ & $\begin{array}{l}-0.106^{* *} \\
(0.049) \\
{[12,861]}\end{array}$ \\
\hline $\begin{array}{l}\text { Officers by Total } \\
\text { Number of Tickets } \\
\text { issued in } 20 \text { Months }\end{array}$ & $<100$ & $\begin{array}{l}-0.234 * * * \\
(0.077) \\
{[4,465]}\end{array}$ & $100=$ & $\begin{array}{l}-0.115 * * \\
(0.058) \\
{[9,788]}\end{array}$ \\
\hline Motorists' Gender & $\begin{array}{c}\text { Male } \\
\text { Motorists }\end{array}$ & $\begin{array}{l}-0.196 * * * \\
(0.055) \\
{[9,190]}\end{array}$ & $\begin{array}{c}\text { Female } \\
\text { Motorists }\end{array}$ & $\begin{array}{l}-0.111 \\
(0.080) \\
{[5,063]}\end{array}$ \\
\hline Day and Night & $\begin{array}{c}\text { Day } \\
\text { 6:00AM } \\
-5: 59 \mathrm{PM}\end{array}$ & $\begin{array}{l}-0.111 * * \\
(0.055) \\
{[10,549]}\end{array}$ & $\begin{array}{l}\text { Night } \\
\text { 6:00PM } \\
-5: 59 \mathrm{AM}\end{array}$ & $\begin{array}{l}-0.439 * * * \\
(0.074) \\
{[3,704]}\end{array}$ \\
\hline Vehicle Age & $=5$ Years & $\begin{array}{l}-0.023 \\
(0.085) \\
{[4,767]}\end{array}$ & 5 Years $<$ & $\begin{array}{l}-0.169 * * \\
(0.076) \\
{[4,475]}\end{array}$ \\
\hline Neighborhood & White & $\begin{array}{l}-0.067 \\
(0.061) \\
{[9,988]}\end{array}$ & Minority & $\begin{array}{l}-0.309 * * * \\
(0.096) \\
{[3,182]}\end{array}$ \\
\hline
\end{tabular}

Note: All control variables in our basic model are also included. We cannot estimate the model separately for female officers because of the small sample size. 
Table 6. Further Robustness Checks

\begin{tabular}{|c|c|c|c|}
\hline & $\begin{array}{c}(1) \\
\text { Controlling for } \\
\text { Motorist } \\
\text { Home Zip Code }\end{array}$ & $\begin{array}{c}(3) \\
\text { Citations Not } \\
\text { Involving } \\
\text { Vehicle Search }\end{array}$ & $\begin{array}{c}(3) \\
\text { African- } \\
\text { American and } \\
\text { Hispanic } \\
\text { Motorists, } \\
\text { Separately }\end{array}$ \\
\hline $\begin{array}{l}\text { Minority Motorist * } \\
\text { Minority Officer }\end{array}$ & $\begin{array}{l}-0.218 * * * \\
(0.053)\end{array}$ & $\begin{array}{l}-0.167 * * * \\
(0.047)\end{array}$ & \\
\hline $\begin{array}{l}\text { African-American Motorist * } \\
\text { African-American Officer }\end{array}$ & & & $\begin{array}{l}-0.094 * * * \\
(0.022)\end{array}$ \\
\hline $\begin{array}{l}\text { Hispanic Motorist } * \\
\text { African-American Officer }\end{array}$ & & & $\begin{array}{l}-0.099 * * * \\
(0.031)\end{array}$ \\
\hline $\begin{array}{l}\text { African-American Motorist * } \\
\text { Hispanic Officer }\end{array}$ & & & $\begin{array}{l}-0.160 * * * \\
(0.035)\end{array}$ \\
\hline $\begin{array}{l}\text { Hispanic Motorist } * \\
\text { Hispanic Officer }\end{array}$ & & & $\begin{array}{l}-0.183 * * * \\
(0.049)\end{array}$ \\
\hline $\begin{array}{l}\text { Number of Observations } \\
\text { Pseudo R-squared }\end{array}$ & $\begin{array}{l}11,281 \\
0.173\end{array}$ & $\begin{array}{c}13,486 \\
0.172\end{array}$ & $\begin{array}{l}14,253 \\
0.156\end{array}$ \\
\hline
\end{tabular}

Note: Robust standard errors are in parentheses. All control variables in our basic model are also included. 
Table 7. Total Number of Citations per Day

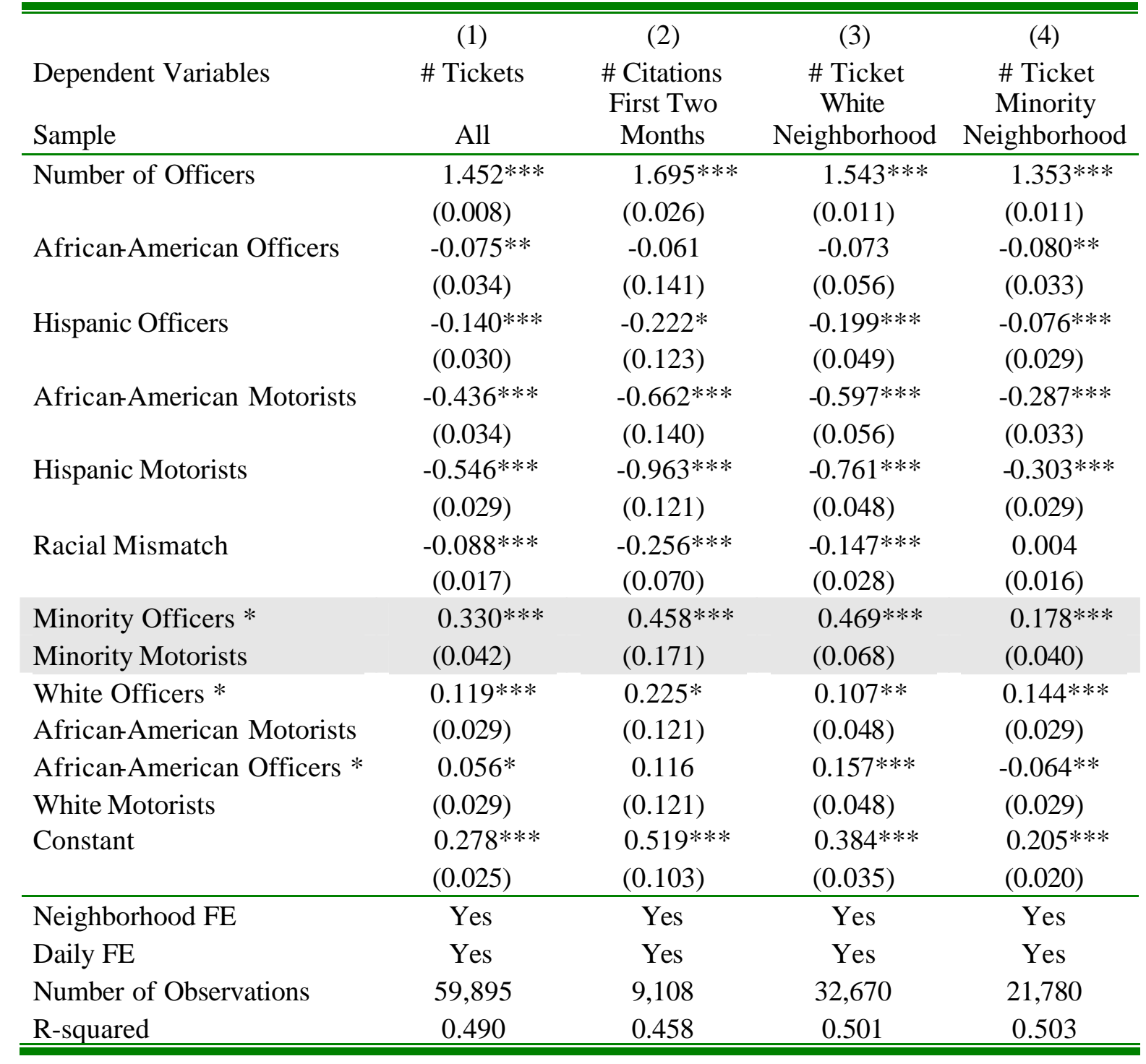

Note: OLS estimates. Robust standard errors are in parentheses, * significant at $10 \%$; ** significant at 5\%; *** significant at $1 \%$. There are 605 days, 9 racial matching pairs, and 11 neighborhoods. The maximum number of observations is $59,895(=605 * 9 * 11)$. 


\section{Appendix Figure 1. Histogram of Speed on Tickets}

(12,116 Tickets in the City of Bloomington from January 2004 to December 2007)

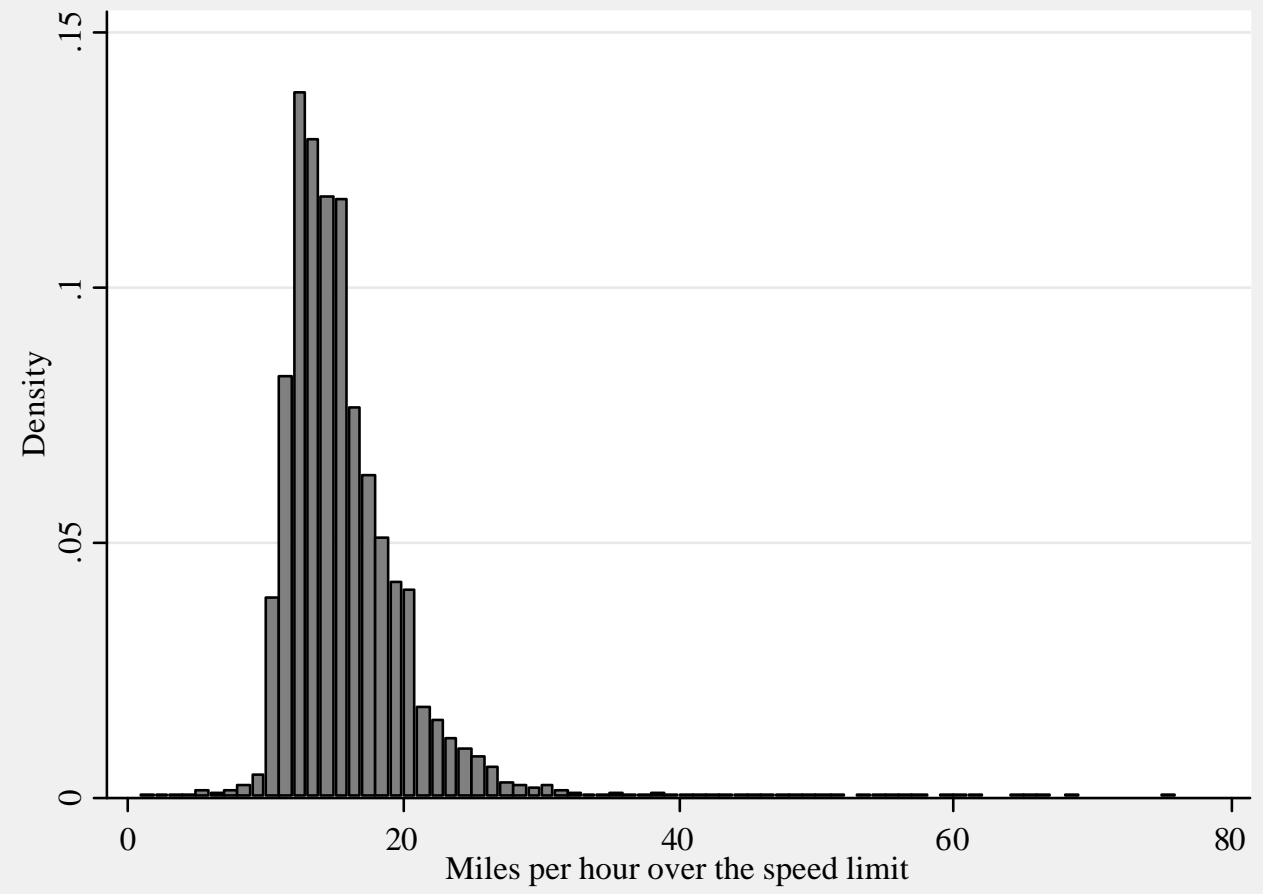

